\title{
O selo postal como objeto de divulgação das ciências
}

Diego Andres Salcedo

\begin{abstract}
Resumo
Indica a utilização do selo postal como objeto de divulgação das ciências. Considera, para tanto, enquanto pressupostos, que o conhecimento científico constitui, cada vez mais, a concepção de Ser-no-mundo tanto do indivíduo, quanto das coletividades; ainda, que objetos imagéticos têm sido utilizados como um recurso discursivo que informa, comunica e interpela ambos, modifica seus mundos e têm papel importante na construção das realidades sociais. Propõe, então, que por meio da análise de selos postais comemorativos brasileiros sejam consideradas três categorias de análise e estudo: Imagem Científica (IC), Imagem Tecnológica (IT) e Imagem Tecnocientífica (ITC). Isso permitirá a identificação, análise e interpretação do discurso científico nos níveis textuais e pictóricos. Contribui aos estudos que utilizam, mesmo que ainda de forma incipiente no cenário educacional e pedagógico brasileiro, o selo postal como um documento que permite a divulgação do conhecimento científico.
\end{abstract} postal.

Palavras-chave: ciência, divulgação científica, educação científica, selo

\begin{abstract}
Indicates the use of postage stamps as an object for and disseminating science. Considers, therefore, as assumptions, that scientific knowledge is increasingly the conception of Being-in-the-world of both the individual and the collectiveness; also, that pictorial objects have been used as a discursive resource that informs, communicates and challenges both, change their worlds and play an important role in the construction of social realities. Proposes that through the analysis of brazilian commemorative postage stamps three categories of analysis and study may be considered: Scientific Images (SI), Technology Images (TI), and Techno-science Images (TSI). This will enable the identification, analysis and interpretation of scientific discourse in textual and pictorial levels. Contributes to studies that use, although still incipient in the brazilian educational and pedagogical systems, postage stamps as a document that may enable the dissemination of scientific knowledge.
\end{abstract}

Keywords: postage stamp, science, scientific dissemination, scientific education.

\section{Introdução}

A estreita relação entre Ciência e Tecnologia (binômio que resultou na abreviatura $C \& T$ e utilizado no singular) é tema das agendas políticas e econômicas de todos os países. No Brasil, até o início do século XXI, essa relação ainda parece ser mal compreendida, estranha e distante do imaginário social. 
Assim também pensa Izquierdo (2005, p. 114) quando afirma que "o desinteresse e desconhecimento da população brasileira sobre a ciência e a tecnologia causa um empecilho para o seu desenvolvimento e redução de sua independência econômica". Izquierdo (2005, p. 114) acredita que existe uma forma de preconceito arraigada na sociedade brasileira: "O Brasil conhece pouco sobre ciência porque há uma crença de que isto é 'coisa de primeiro mundo' e ignora-se a realizada no país".

Nas agendas mencionadas, a discussão sobre essas duas culturas considera em ampla medida a direta relação que os produtos científicos e tecnológicos têm com o desenvolvimento e o progresso. A ampliação desse escopo temático encontra espaço nas instituições de pesquisa e nas escolas de pensamento.

Esse debate sobre as concepções atuais das Ciências e das Tecnologias, por sua vez, ultrapassa os limites das instituições sociais, perpassa as mídias (mas não antes sem ramificar-se nas formações e estratégias discursivas), e encontra lugar nas distintas esferas sociais, sejam elas públicas ou privadas.

Identificar, descrever e analisar as semelhanças e diferenças entre as Ciências e Tecnologias, tanto com relação aos aspectos qualitativos como quantitativos, envolve inúmeras variáveis num processo histórico complexo e intricado. É um movimento no tempo-espaço de acordo com as condições de possibilidades de combinações dessas variáveis. As Ciências e as Tecnologias, não obstante essenciais, são apenas duas variáveis concernentes ao desenvolvimento e progresso.

O fato de usar esses termos no plural é proposital e vai de encontro à noção singular de C\&T. Opõe-se à noção de uma Ciência e Tecnologia universal, preponderante e hegemônica. Ciência e Tecnologia são ramificações de ditos e não-ditos passados que tangenciam a superfície de um continuum histórico no mundo das idéias, no imaginário humano. Decerto, existem fios condutores que podem explicar conceitos como "Unidade Científica", "Campo Científico", "Disciplina Científica" ou "Inovação Tecnológica", mas isso não significa que se concebam como válidos para todos e em todos os lugares.

O interesse sobre esse assunto pode ser explicado, de forma sucinta, pela convergência de múltiplos fatores. Numa primeira análise, percebe-se que tanto as Ciências como as Tecnologias estão culturalmente imbricadas no sistema capitalista mundializado. As práticas de produção, distribuição e consumo de bens e serviços, além dos modelos educacionais, são constantemente permeados por culturas tecnocientíficas. Esse sistema interpreta os significados, as aplicações e o somatório de conhecimentos dessas culturas, além de apropriar-se delas para sua própria reprodução. 
"A rigor, a tecnologia não precisa ser nova ou complexa, mas, nas sociedades modernas, o termo vem ganhando conotação de algo novo $e$ significativamente mais avançado, sob a forma de novos bens e processos de produção, distribuição e utilização." (Rosenthal, apud, Pinheiro e Pinheiro, 2002, p. 157).

Um outro fator se refere ao fato de que as Ciências do ponto de vista das instituições (tanto aquelas onde se realizam pesquisas, assim como aquelas que fomentam as pesquisas), das comunidades ou sociedades científicas (em grande medida, de atuação internacional), da comunicação científica (sistema de publicações), e da popularização e educação científica, possuem um enorme valor potencial que permite flexibilidade, continuidade e aplicabilidade nos distintos setores sociais.

Um terceiro aspecto diria respeito à impossibilidade e à inadequação, apesar de não ser o foco deste trabalho, de analisar esses termos sem levar em consideração a sua correlação com noções econômicas, ecossistêmicas, éticas e históricas. Por exemplo, do ponto de vista histórico, seria concebível um estudo sobre os conceitos sistematizados por Aristóteles sobre Ciência (episteme) e Técnica (techné), revistos por Granger (1994), o qual representa um marco fundador do pensamento ocidental. Outro exemplo trataria sobre a utilização da tecnologia no sistema capitalista sob duas perspectivas: a de Marx (apud, KATZ, 1996) e a de Schumpeter (1998).

Sabe-se, no entanto, que as Ciências e as Tecnologias são variáveis dentro de um complexo sistêmico mais amplo, ramificadas na superfície não linear, descontínua e de rupturas histórico-revolucionárias. Em alguns períodos as Ciências e as Tecnologias são identificadas como atividades humanas distintas e desconexas, em outros elas se tornam praticamente indissociáveis. Mais adiante, elas serão analisadas com relação às características mencionadas.

Antes, porém, é prudente sugerir algumas indagações que norteiam os estudos que vêm sendo realizados. Como é o relacionamento entre as Ciências, as Tecnologias e a Comunicação? Quais são os objetos que validam uma abordagem dessa tríade? Por quem, onde, quais e como as imagens das culturas tecnocientíficas são criadas? Em que suportes de informação são registradas e disseminadas? Como criam correlações de legitimação com e sobre as pessoas? Até que ponto esse suportes (impressos e eletrônicos) servem como alicerce ao status quo das culturas tecnocientíficas? Como lê-los? Como educar as futuras gerações para lidar com essas imagens? Essas indagações são pertinentes e não compactuam com a afirmação de Ellul (1968, p. 6), quando sugere que "...discutir as relações entre as Ciências e as Tecnologias seja um verdadeiro mata-burro". 


\section{Difusão Científica e o Selo Postal}

Ao longo da história humana, a disseminação da informação científica acompanhou o desenvolvimento da produção do conhecimento. Durante o século XIX, paralelamente ao crescimento exponencial desse conhecimento, houve uma ampliação e aprimoramento das ferramentas de difusão dos saberes. Esses meios de divulgação acompanharam as sociedades ou comunidades científicas e, de certa forma, ainda o fazem.

Afinal, sem divulgação, a comunidade permanece às cegas das descobertas relevantes no campo da ciência e tecnologia, desconhece os pesquisadores e suas atividades e não acompanha os trabalhos desenvolvidos nas instituições de pesquisa. Logo, a comunicação científica tem um relevante papel social, tanto para o progresso da ciência como para o amadurecimento social. $\mathrm{Na}$ mesma direção, Gomes e Salcedo (2005, p. 81) afirmam:

"comunicar conhecimentos gerados nas instituições de pesquisa é difundir informações para que a comunidade científica possa desenvolver e aprofundar os conhecimentos e também para que a sociedade tome ciência do papel desses conhecimentos na melhoria de sua qualidade de vida. Nesse sentido, tanto a disseminação quanto à divulgação da ciência são relevantes para essa difusão."

Para que o progresso social torne-se uma realidade experimentada na vida cotidiana é imprescindível o desenvolvimento científico e tecnológico, associado a um processo contínuo de socialização da informação. Apresentar resultados de investigações científicas à sociedade é algo próprio da ciência. Meadows (1999, p. vii) corrobora com essa assertiva: "A comunicação situa-se no próprio coração da ciência [...]. Qualquer que seja o ângulo pelo qual a examinemos, a comunicação eficiente e eficaz constitui parte essencial do processo de investigação científica".

É extremamente relevante às sociedades ter acesso ao conhecimento científico, tornando-se também evidente o papel social da mediação dessa informação. Para Oliveira (2002, p. 13)

"[...] o acesso às informações sobre C\&T é fundamental para o exercício pleno da cidadania e, portanto, para o estabelecimento de uma democracia participativa, na qual grande parte da população tenha condições de influir, com conhecimento, em decisões e ações políticas ligadas a C\&T [...] No entanto, o acesso às informações sobre C\&T como um dos mecanismos que pode contribuir de maneira efetiva para a formação de uma cultura científica deve ser facilitado ao grande público carente delas."

Situada num complexo sistema de comunicação, entre as várias facetas da divulgação científica, o tipo de suporte onde a informação científica é veiculada torna-se um aspecto relevante quando é proposta uma avaliação da produção de conhecimento científico e sua 
divulgação.

É imperativo e relevante que todo e qualquer suporte disponível seja utilizado para contribuir, cada qual à sua forma, no desenvolvimento de modelos de divulgação científica. Dentre as diversas tipologias documentais que podem servir a esse propósito está a documentação filatélica, que inclui o selo postal.

Esse pequeno pedaço de papel, indiferente às diversas formas como se apresenta e aos suportes aos quais é agregado, elimina distâncias, preserva na forma de texto e imagem, com criatividade, uma possível história da humanidade. Resgata, pois, na forma de documento temático, as pessoas e suas feituras, efemérides, eventos, símbolos (locais, nacionais e internacionais), celebrações, costumes, tradições, processos e o tempo (memória), de forma particular e geral. Funciona como um elo entre os indivíduos, seu processo histórico e os diversos e distintos conhecimentos.

O selo postal, enquanto documento, é constituído de elementos químicos (ex.: goma) e físicos (ex.: papel), formatos diversos, espaço reduzido, além de conteúdos múltiplos e correlacionados (SALCEDO, 2013). Além disso, "aos selos poder-se-ia aplicar a síntese feita por Abraham Moles para o cartaz. Eles têm a função de informar e de educar" (Erbolato, 1983, p. 115).

Se por um lado, Salcedo (2008, p. 5) sugere que as informações "textuais e pictóricas" registradas nesses pequenos artefatos culturais, constituem-se discursos de conteúdo endógeno e exógeno, que passam despercebidos ao leitor comum que, por sua vez, apenas os identificam como taxas devidas ao Correio para envio de missivas postais. Então, pelo outro lado, afirma Altman (1991, p. 4): "stamps have become useful ideological and cultural artifacts, and a means for governments to [...] promote certain images at home and abroad".

Propõe-se que o selo postal, "documento produzido pelo Estado", como confirma Salcedo (2006, p. 1), é um meio que pode ser considerado aliado ao processo de difusão e, portanto, à socialização da informação científica. Ainda, é um documento de salutar positividade no que diz respeito ao seu uso por educadores em atividades das mais diversas e distintas. Assim, é válido e possível um esforço nesse sentido se forem analisadas, para além da relevância e função social, as características diversas que lhe é inerente.

\section{As Ciências e as Tecnologias: "tecnociências"?}

O uso do termo tecnociências, "emprestado dos construtivistas [...] apenas significa a junção [das Ciências] com a tecnologia dela derivada e que retroativamente a alimenta" (Rosa, 2005, p. 13). Como será sugerido mais adiante, o uso desse termo apenas faz sentido a partir do 
terceiro período discutido. Falar de tecnociências até a Segunda Guerra Mundial é cair em contradição com os próprios conceitos que tangenciam a superfície discursiva do termo.

O primeiro período abrange desde a denominada Revolução Agrícola até a Revolução Industrial. Esse período, por sua vez, pode ser subdividido em dois estágios menores: aquele que compreende desde a Antiguidade até o Renascimento e o segundo, que ficou conhecido como Ciência Moderna.

No primeiro estágio, em cada civilização, havia indagações sobre o Universo pelas quais os fenômenos comuns ao planeta eram explicados de forma distinta. Contribuíam para isso, a inexistência ou deficiência de mecanismos de difusão das idéias, as condições ambientais adversas e extremas, as distâncias territoriais, além das poderosas crenças mítico-religiosas.

O estágio da Ciência Moderna na Europa parece surgir pela confluência de diversos e distintos fatores. O declínio do império islâmico, que deixou como herança uma grande síntese de conhecimentos. A Renascença, que entre outras idéias, pregava o individualismo. A Reforma e a Contra-Reforma, que debilitaram a hegemonia de uma religião institucionalizada. O sistema capitalista, em contraponto ao mercantilista, que simpatizava com a experimentação e crença na exploração da natureza (quando irão surgir os estudos da fauna e flora). As viagens para alémmar, que revelaram uma profusão de novos fenômenos. Os mais variados legados conhecimentos e práticas científicas, já tornaram possível identificar métodos de pesquisa. A estimulação sobre a dominação das tecnologias de guerra cada vez mais avançadas. O surgimento da imprensa, no século XV propiciou a difusão de conhecimento em escala sem precedentes.

Assim como aumentavam as produções e impressões escritas, crescia o número de pessoas interessadas no avanço dos conhecimentos e suas aplicações. Nesse período surgem as primeiras sociedades e escolas acadêmicas, assim como os primeiros periódicos científicos. Desse momento em diante, pode-se afirmar que existia uma Ciência institucionalizada na Europa, como uma atividade distinta da filosófica, com regras próprias de validação das idéias, do registro do conhecimento, do reconhecimento e de sua função social.

Esse primeiro período caracteriza-se pelo fato de que as Ciências e as Tecnologias utilizadas na produção de bens e serviços eram independentes. A fluidez e complexidade dessa interação, naquela Europa, são pouco perceptíveis. As novas idéias das ciências eram incipientes, pouco e lentamente difundidas. Por outro lado, as tecnologias ainda restringiam-se ao emprego e uso de ferramentas, artefatos e construções que tinham como objetivo complementar as habilidades ou amplificar a força das pessoas.

O segundo período pode ser considerado aquele entre a Revolução Industrial e a Segunda Guerra Mundial. O fator primordial desse período foi a introdução de máquinas no processo de produção de bens. Somam-se a esse aspecto, dentre outros, maior crédito no mercado, 
organização do trabalho e o surgimento dos mercados produtivos de carvão, ferro, aço e eletricidade.

Por um lado, as máquinas permitiram a realização dos trabalhos em escalas e velocidades muito maiores. Pelo outro, essas tecnologias começam a substituir o indivíduo no processo produtivo e passam a ser figuras centrais nas economias. A Europa do século XX era industrializada. Segundo Hall e Hall (1964, p. 219), "os primórdios da tecnologia moderna [...] deveram virtualmente nada [às Ciências], e tudo aos frutos da tradição da invenção nas artes mecânicas e artesanais". Nesse quadro europeu é difícil encontrar vestígios que comprovassem o intercâmbio de idéias e aplicações entre os estudiosos das Ciências e as pessoas que inventavam as máquinas utilizadas pelas primeiras indústrias.

O terceiro momento vai desde o advento da Segunda Guerra Mundial até os dias atuais. Nesse período, a produção das Tecnologias, por meio do uso contínuo de métodos e descobertas científicas, ganha campo e se ramifica para todas as atividades sociais, políticas, econômicas e culturais. Foi durante esse conflito mundial que os cientistas, pesquisadores e inventores foram mobilizados na procura por soluções tecnológicas com relação aos problemas inerentes à Guerra.

Após o fim da Segunda Guerra torna-se evidente que a capacidade científica e tecnológica passaria a ser um dos grandes determinantes do poder e do saber nas esferas políticas, econômicas e militares. Segundo Pirró e Longo (1987, p. 107), "a disponibilidade de tecnologias avançadas abriria portas para o domínio sobre os demais fatores". Como conseqüência, prossegue o autor, "A competição entre mercados e nações seria determinada pela capacidade de inovação e produtividade". Ninguém poderia garantir uma paz duradoura, o que levou empresas e Estados a visualizar as Ciências e as Tecnologias como categorias de primeira ordem. Ampliaram a atuação político-econômica dos Estados sobre esses campos específicos, criaram órgãos e Leis que reconheceram, fomentaram e legitimaram mecanismos, procedimentos e infra-estruturas.

Não obstante o que foi mencionado até aqui, é relevante destacar três aspectos da relação entre as Ciências e as Tecnologias apresentados por Kneller (1980). O primeiro aspecto foi resultado oriundo de algumas escolas européias e defende que "todas as inovações tecnológicas foram fundamentadas e impulsionadas por específicos avanços científicos, com suas teorias, leis e dados" (Kneller, 1980, p. 247-248).

O segundo aspecto, segundo Kneller (1980, p. 248), trata sobre o ponto de vista da escola soviética marxista, o qual dizia que "ao contrário do ponto de vista anterior, o parceiro fundamental e determinante fora (e seguia sendo), a tecnologia". Percebe-se que esse segundo aspecto surge mais com um propósito ideológico, mais uma das tantas utopias propostas durante o século XX. O terceiro aspecto é aprofundado por Kneller (1980, p. 249), com uma visão mais recente: 
"hoje, o ponto de vista mais comum é que a ciência e a tecnologia se desenvolveram, em sua maior parte, independentemente uma da outra até cerca de 100 anos atrás. De acordo com o historiador da ciência A. Rupert Hall, 'virtualmente todas as técnicas da civilização até uns duzentos anos atrás foram obras de homens tão incultos quanto anônimos'."

O problema em questão parece melhor elaborado por Kneller (1980, p. 252), quando afirma que "a Ciência, por seu turno, foi aplicada à invenção e ao aperfeiçoamento tecnológico por meios mais sutis e variados do que até hoje se deu conta". Outro ponto que chama a atenção é o fato da evolução do método científico de pesquisa ter exercido forte impacto disciplinar sobre as invenções tecnológicas. De fato, hoje, existe uma tendência para que as Ciências e as Tecnologias sejam interdependentes, correlacionadas e complementares.

Entende-se, para além do que já foi exposto, que as Tecnologias não podem ser concebidas apenas como máquinas e mecanismos, no sentido concreto dos termos. Elas podem ser compreendidas, também, como "articulações de estruturações tecnosociais". Nesse sentido, as Tecnologias constituem "dinâmicas sociais que surgem nas sociedades industriais e seguem avançando", segundo alguns autores, "nas pós-industriais" (Morais, 2007, p. 66).

O que se percebe, apesar da revisão da literatura não ser de forma alguma exaustiva, é a dificuldade de identificar, de forma clara, a relação entre os conceitos das Ciências e das Tecnologias. Isso se deve ao fato de que ambas são conceitualmente ramificadas em superfícies correlacionadas e, que por sua vez, estão contextualizadas num processo histórico metamórfico. No entanto, por razões didáticas, tentar-se-á identificar por meio de análise dos códigos icônicos registrados nos selos postais comemorativos brasileiros, conteúdos que remetam à imagem das Ciências, das Tecnologias e de ambas quando for o caso.

\section{Educação científica visual por meio de selos postais}

Bessis (1994, p. 159) sugere que a palavra imagem vem do Grego (mimos = imi-tação, e genes $=$ nascido de "[...] nascida da imitação, transmite ao que vê tanto o conhecido como o desconhecido, ornando-os de um valor estético e significativo". Apela para a imaginação daquele que produz e interpela aquele que vê o produto imagético.

Ainda que trabalhar com conceitos seja uma atividade fluída e incerta, talvez até ininterrupta, é pertinente ampliar a visão sobre os conceitos de imagem. No campo da Neurologia, Damásio (2000, p. 24-25) afirma que "imagem designa um padrão mental em qualquer modalidade sensorial". Em outro momento de sua obra, o autor explica com maior detalhe sua concepção de imagem tomada como um sinônimo de representação. 


\begin{abstract}
"Refiro-me ao termo imagens como padrões mentais com uma estrutura construída com os sinais provenientes de cada uma das modalidades sensoriais - visual, auditiva, olfativa, gustatória e sômato-sensitiva. A [última] modalidade inclui várias formas de percepção: tato, temperatura, dor, [etc.]. A palavra imagem não se refere apenas a imagem 'visual' e, também não há nada de estático nas imagens...As imagens de todas as modalidades 'retratam' processos e entidades de todos os tipos, concretos e abstratos. As imagens também 'retratam' as propriedades físicas das entidades $e$, às vezes imprecisamente, às vezes não, as relações espaciais e temporais entre entidades, bem como as ações destas. Em suma, o processo que chegamos a conhecer como mente quando imagens mentais se tornam nossas, como resultado da consciência, é um fluxo contínuo de imagens, e muitas delas se revelam logicamente inter-relacionadas...Pensamento é uma palavra aceitável para denotar esse fluxo de imagens" (Damásio, 2000, p. 402-403).
\end{abstract}

Por meio das afirmações anteriores, Contrera e Baitello Jr. (2006, p. 117-118) vão sugerir duas questões pertinentes aos estudos das imagens no âmbito das teorias da Comunicação e das Mídias: 1. "O fluxo de mão dupla existente entre a motivação interna e a captação externa, que se articula na criação das imagens com as quais pensamos". Aqui caberiam as discussões sobre Teoria da Imagem (psíquicas e oníricas), da Recepção e do Imaginário. 2. "As conseqüências (sócio-ecológicas e eco-psicológicas) do predomínio avassalador dos sistemas comunicativos em detrimento das outras modalidades perceptivas". Aqui é possível estudar de forma crítica sobre as "eras de exacerbação da visualidade, do simulacro e da iconofagia".

Assim, as imagens pertencem aos universos interior (endógeno) e exterior (exógeno), humanos. Vestígios imagéticos compõem o pretérito da humanidade, situam-se no presente e prosseguirão no futuro. As suas formas de interpelação não devem remeter a uma suposta linearidade histórica, muito menos sugerir o mesmo com relação ao modo de leitura, mas a um emaranhado feixe de relações de poder e saber.

O que pode ser interessante discutir é que a imagem, enquanto objeto de análise, revela distintas dimensões da experiência social, a multiplicidade de grupos humanos (grupos sociais) e seus modos de relacionamento. O momento atual amplia a discussão proposta, no século XX e sugere maior complexidade sobre o assunto. Isso se dá, sobretudo, ao levar em conta o advento da midiatização das culturas atuais, no sentido de que há uma predominância da imagem em relação à hegemonia das formas lingüísticas midiáticas mais antigas. A imagem, situada no centro do palco midiático, sugere uma situação panóptica.

"A voga dos estudos de "cultura visual" assinala com clareza [...] aquilo que já foi chamado de pictorial turn, em sequência ao linguistic turn de décadas 
anteriores, que chamaram a atenção para o texto antropológico ou sociológico na produção de conhecimento (Meneses, 2003, p. 21)."

Neste artigo, a imagem será considerada enquanto objeto de estrutura significante, que possibilita construção de sentidos, além de supor processos de decodificação e interpretação. Parte desse processo remete à leitura de seus códigos icônicos. Surge o significado ao leitor a partir da interpretação dos conteúdos, do contato com a interface imagética, e da disposição técnica do suporte.

Portanto, como foco do trabalho, foi feita uma análise de alguns aspectos conceituais e históricos das Ciências e das Tecnologias, por meio da revisão de literatura, o que ajudou na identificação daquilo que será denominado como Imagem Científica (IC), Imagem Tecnológica (IT) e Imagem Tecnocientífica (ITC).

Essas três categorias foram identificadas a partir das informações registradas nos selos postais comemorativos brasileiros emitidos no século XX, mais precisamente de 1900 até 2000 (SALCEDO, 2010). Por escolha metodológica, foram analisados apenas os selos postais do tipo comemorativo. No entanto, nada garante que as categorias serão facilmente destacadas. Como disse Bachelard (1996, p. 18), "na vida científica os problemas não se formulam de modo espontâneo. Para o espírito científico [...] nada é evidente [...], nada é gratuito. Tudo é construído".

Tanto do ponto de vista teórico como prático existem complicadores capazes de ofuscar a visibilidade das categorias propostas. A atividade científica pressupõe tanto o diálogo com o objeto de estudo assim como a construção ou aperfeiçoamento das ferramentas, mecanismos e modelos que permitam investigá-lo, na tentativa de produzir algo chamado conhecimento, sempre provisório e incompleto, sujeito a crítica e retificações. Sendo assim, como forma de explanação visual, será mostrada por meio de três selos postais comemorativos sua correlação textual-imagética para ilustrar cada tipo de imagem sugerido anteriormente (IC, IT e ITC).

Cada imagem será analisada de forma que a proposta dos trabalhos encontre uma adequação válida, objetiva e clara. A breve descrição é inicial e, com certeza, deverá se ampliada no decorrer das atividades. Dentro do possível, as dimensões das imagens retratam fielmente o tamanho original dos documentos originais. As cores não serão consideradas na análise. Com o objetivo didático de indicar quais e como esses elementos se manifestam, mostramos, a seguir, um exemplar (SALCEDO, 2010). 


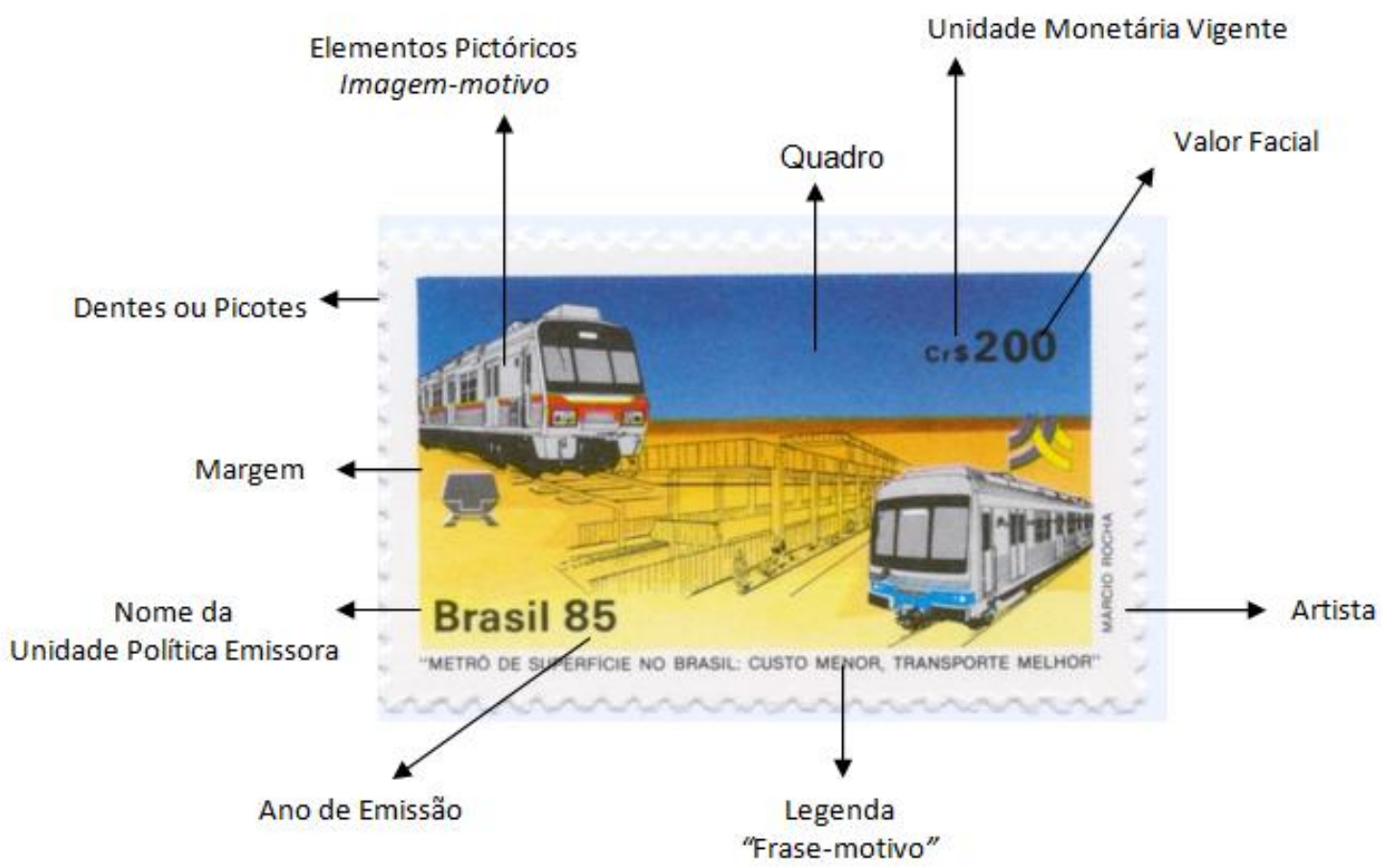

Usualmente, mas não necessariamente, entre o limite da margem e os picotes é inserida a legenda (frase-motivo). Em alguns casos, outras informações podem ocorrer: ano de emissão, nomes de pessoas, nomes de lugares, nome do artista ou artistas designados à elaboração da ilustração ou sigla do órgão impressor do selo postal (ex.: CMB - Casa da Moeda do Brasil).

Diferentemente de outros tipos de selos postais, os comemorativos têm sua tiragem e seu período de validade pré-determinados pelos Atos Normativos e Editais. Por convenção, três elementos verbovisuais devem ser, obrigatoriamente, impressos seguindo um padrão normativo internacional: motivo de sua emissão, o valor facial e o nome do país ou instituição emissora.

Brait (2005, p. 97) sugere que ao trabalhar com "textos visuais ou verbovisuais (foto e sua legenda, a pintura e seu título...)" assumamos a "sua textualidade, sua discursividade". Barthes (2007, p. 5) vê nessa relação "um entrelaçamento que busca garantir a circulação dos significantes". Nesse sentido, é necessário fazer a seguinte divisão: Elementos verbais: o nome do país emissor, ano de emissão, motivo da emissão (legenda => frase-motivo), nome do artista, unidade monetária e o valor facial; Elementos visuais: todos os elementos verbais e os elementos pictóricos (imagem-motivo). 


\section{Um olhar atento}

Um selo postal pode ser analisado fazendo uso de distintos enfoques teóricometodológicos de análise textual e imagética, assim é pertinente esboçar algumas questões a esse respeito. $O$ quadro a seguir indica algumas tendências metodológicas de análise imagéticotextual utilizadas desde o século XX e que não pretende ser exaustiva ${ }^{1}$.

\begin{tabular}{|c|c|}
\hline Autor/es & Metodologias \\
\hline Panofsky (1939) & $\begin{array}{l}\text { Método Iconológico: descrição pré-iconográfica, } \\
\text { análise iconográfica e iconologia. }\end{array}$ \\
\hline Eco (1968) & $\begin{array}{l}\text { Sistema de códigos visuais: verbal e visual } \\
\text { (icônico) }\end{array}$ \\
\hline Barthes (1970) & $\begin{array}{l}\text { Abordagem Semiológica: denotação, conotação, } \\
\text { ancoragem, revezamento. Retórica da Imagem. }\end{array}$ \\
\hline Floch (1981) & Semiótica Estrutural. Teoria Gerativa de Sentido. \\
\hline Joly (1994) & $\begin{array}{c}\text { Descrição da Imagem. Reprodução do Texto. } \\
\text { Separação e Análise da Imagem (plástica, icônica } \\
\text { e linguística) }\end{array}$ \\
\hline Prosser (1998) & $\begin{array}{l}\text { Antropologia e Sociologia Visual. Etnografia. } \\
\text { Evidência fotográfica. } \\
\text { Iconografia e Iconologia, Mitologias. } \\
\text { Análise de gênero e técnica, forma, estilo e } \\
\text { semiótica. Estruturalismo, reconstrução, contexto } \\
\text { físico. Hermnêutica. }\end{array}$ \\
\hline Emmison e Smith (2000) & $\begin{array}{c}\text { Análise de Evidência em duas dimensões: } \\
\text { quantitativa e qualitativa }\end{array}$ \\
\hline Leeuwen e Jewitt (2001) & $\begin{array}{l}\text { Análise do conteúdo. Estudos Culturais. } \\
\text { Semiótica. Iconografia. Perspectiva terapêutica. } \\
\text { Sociosemiótica. Etnometodologias. }\end{array}$ \\
\hline Rose (2001) & $\begin{array}{l}\text { Interpretação Compositiva. Análise de Conteúdo. } \\
\text { Semiologia, Psicanálise, Análise do Discurso. }\end{array}$ \\
\hline
\end{tabular}

${ }^{1}$ A obra "Imagem: cognição, semiótica, mídia" de Lúcia Santaella e Winfried Noth (2005) tem uma bibliografia bastante extensa e contempla o estudo da imagem em múltiplos sentidos.

R. B. E. C. T., vol 7, núm. 2, mai-ago.2014 ISSN - 1982-873X 


\begin{tabular}{|c|c|}
\hline Emery (2002) & $\begin{array}{c}\text { Abordagem de } 7 \text { marcos interpretativos: } \\
\text { formalista, desconstrucionista, gênero, cultural, } \\
\text { semiótico, psicanalítico e social realista. }\end{array}$ \\
\hline Walker e Champlin (2002) & $\begin{array}{r}\text { Forma e conteúdo. Análise do Conteúdo. } \\
\text { Iconografia e Iconologia, Mitologias. } \\
\text { Análise de gênero e técnica, forma, estilo e } \\
\text { semiótica. Estruturalismo, reconstrução, contexto } \\
\text { físico. Hermenêutica. }\end{array}$ \\
\hline
\end{tabular}

Quadro 1 - Autores e aparatos teórico-metodológicos para análise de imagens.

Fonte: Adaptado e atualizado a partir de Hernández (2007, p. 49-50).

Tratar com selos postais seja como objeto de pesquisa, seja como artefato de coleção, estabelece alguns limites. Um deles diz respeito à análise de imagens. Sobre isso Rose (2001, p. 26 apud, Raento; Brunn, 2005, p. 147) comenta que "não muito tempo atrás, existia pouco debate na literatura sobre como imagens poderiam ser lidas, não obstante a explosiva diversificação e desenvolvimento tecnológico da cultura visual, além da crescente demanda de estudos orientados à visualidade".

Olhar nossa amostra não tem como objetivo recompor a experiência perdida no passado. Não pensamos que a polêmica teórica que versa sobre a legitimidade ou não dos artefatos utilizados como provas caiba neste trabalho, mas, decerto, é fundamental para os estudos de análise de imagens ou em pesquisas de cunho histórico.

Por outro lado, um selo postal não é apenas o congelamento, a irreversibilidade ali mostrada. Ele faz saber, também, que existiu uma autoria e uma técnica. Certamente é possível olhar o selo enquanto objeto de estudo histórico, entendendo que sua leitura é um processo hermenêutico, como propõe Ferro (1984, p. 3-4, apud, CUNHA, 2006, p. 222):

“...agentes da história (na medida em que as imagens protagonizam, por elas mesmas, ações sociais e políticas), como engrenagens de um sistema de relações entre representações técnicas e as sociedades que as produzem $e$ consomem e, finalmente, como sintomas do próprio movimento da história."

Além disso, todo selo postal comemorativo é um artefato intencionalmente criado, para além de sua função administrativa. No caso específico do selo postal do tipo comemorativo, existe uma intenção. Esse fato não elimina, em hipótese alguma, a fruição estética do artefato. No entanto, a discussão estética de cada peça do corpus não é o foco deste estudo. De certa 
maneira, a intenção e o testemunho registrado em cada peça são inseparáveis ou como afirma Kossoy (2003, p. 50) "componentes de um binômio indivisível".

Do ponto de vista da análise de imagens, os conceitos que permitem essa ação resultam de um longo processo histórico-social. Burke (2004, p. 222), por exemplo, considera três escolas de análise de imagens e como elas estão interconectadas:

"...os estruturalistas são criticados por uma falta de interesse em imagens específicas (que eles reduzem a simples padrões), e também por uma falta de preocupação com a mudança. Em reação contra este enfoque desenvolveu-se um movimento conhecido como 'pós-estruturalista'. Se os iconógrafos enfatizam a produção consciente de significado e os estruturalistas, como os freudianos, destacam os significados inconscientes, o foco do pósestruturalismo recai na indeterminação, na 'polissemia', ou no que Jacques Derrida chamou de 'jogo infinito de significações'. Eles estão preocupados com a instabilidade ou multiplicidade de significados e com as tentativas dos produtores de imagens de controlar esta multiplicidade por meio, por exemplo, de rótulos e outros 'iconotextos'."

Tacca (2005), por sua vez, sugere uma ciência da significação em que três aproximações são possíveis. A "abordagem semiológica", que utiliza conceitos de Roland Barthes (1990): denotação, conotação, ancoragem, studium e punctum. A "abordagem semioticista", que recorre às idéias de Philippe Dubois (1986): intenção e referente. Por fim, "o ícone como símbolo social construído", que considera conceitos como Outro e símbolo, numa concepção que se aproxima da semiótica de Charles Sanders Peirce, importantes para entendermos criticamente as imagens, por meio de estudos de Goldberg (1991) e do próprio Tacca $(1995,2001)$.

De certa maneira nos sentimos em uma posição ambígua com relação ao enfoque metodológico. Parece com a situação experimentada por Barthes (1990) em sua "abordagem semiológica". Por um lado, como ele, não estamos analisando o selo postal sob o ponto de vista de um produtor - "operator". Também não pretendemos falar como aquele que é representado pelo texto - "spectrum". Mas nos vemos na posição de como observadores/interpretantes "spectator", ligados afetivamente ao objeto analisado. Observadores que fizeram escolhas estabeleceram critérios baseados, também, na nossa experiência, fragilidade e história de vida.

Iremos nos apropriar, portanto, desses conceitos propostos por Barthes (1990) - operator, spectator, spectrum, studium e punctum - e da sugestão metodológica de Agustín Lacruz (2006, p. 129), que entende "a determinação do conteúdo com um processo que perpassa três fases distintas: descrição, identificação e interpretação". A partir deles, pensamos que é adequado fazer uma adaptação com relação aos estudos de selos postais. 
Assim, dar-se-á essa adequação da seguinte maneira: o operator é o Estado e aquele conjunto de pouquíssimas pessoas que possibilitam a emergência de cada selo postal; o spectator, que pode ser um colecionador, um jornalista filatélico, um comerciante, um atendente do Correio, uma pessoa na fila do Correio, um pesquisador. Um conjunto de pessoas que manuseiam o selo postal no seu cotidiano. Alguns o tocam, o lambem, o destroem e outros, por vezes, o olham; o spectrum é o selo postal, propriamente dito, no entanto, num nível em que a frase-motivo e a imagem-motivo sejam postos em evidência, alvo de análise e interpretações. Por fim, o punctum, aquilo que salta aos nossos olhos, o que nos selos nos alcança afetivamente.

\section{Exemplo de Imagem Científica (IC) ${ }^{1}$ :}

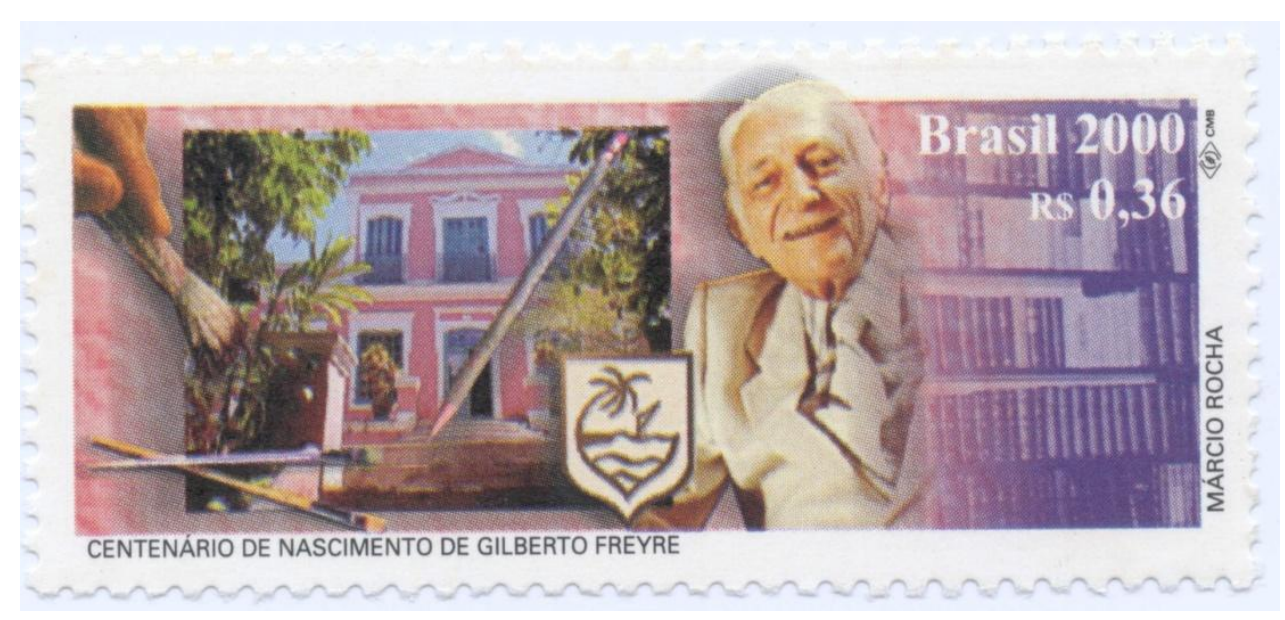

Figura 1: Imagem Científica (IC) - Coleção do autor

Na margem inferior, entre a moldura e a dentição (tipo de recorte, por máquina, que separa o selo de outros), há o seguinte código textual: Centenário de Nascimento de Gilberto Freire. Na margem direita está escrito: Márcio Rocha (artista). Outro dois códigos textuais formam imagem, no entanto estão localizados dentro da moldura, ambos em tom de branco: Brasil 2000 e $R \$ 0,36$.

10 livro publicado, em 2010, pela Editora da Universidade Federal de Pernambuco, resultado de pesquisa feita no Mestrado em Comunicação, indica e ilustra uma amostra de 104 selos postais comemorativos brasileiros, emitidos no século XX, com características verbovisuais que permitem categorizá-los enquanto imagens científicas. São esses selos postais, em que pese a possibilidade de aumentar a amostra, ao considerar um levantamento a partir do ano 2000, que podem ser utilizados pelos educadores científicos nas salas de aula, em exposições, em encontros como o da SBPC, em mini-cursos oferecidos dentro da programação de encontros científicos, em palestras etc. Parte dessa amostra é mostrada no final deste artigo, por meio de quatro lâminas. 
Como códigos imagéticos podem ser destacados: um símbolo heráldico (mar, jangada e coqueiro); um lápis; dois pincéis e dedos segurando o que parece ser uma "mão" ou tipo de "pincel". Todos estão em primeiro plano, sobrepostos às imagens da atual Fundação Gilberto Freire (enquadrado em outra moldura) e do próprio cientista e sua biblioteca.

A correlação dos códigos icônicos sugere a classificação deste selo como IC. Apesar de que alguns símbolos (livro, pincel, lápis e o casarão da Fundação G. F.) poderem ser classificados como tecnologias, não é o foco da temática de emissão do selo, que trata apenas da comemoração do centenário de nascimento do cientista em questão. $O$ selo tem por motivo de emissão a pessoa, o cientista e não as tecnologias. Essa característica específica atesta o fato da classificação dessa imagem como, apenas, científica.

\section{Exemplo de Imagem Tecnológica (IT):}

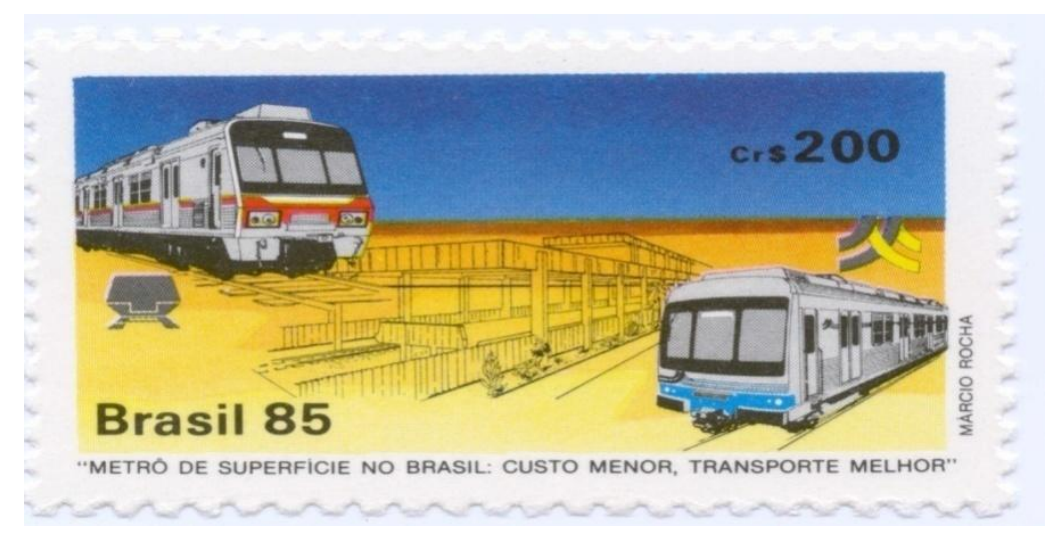

Figura 2: Imagem Tecnológica (IT) - Coleção do autor

Na margem inferior, entre a moldura e a dentição, há o seguinte código textual: Metrô de superfície no Brasil: custo menor, transporte melhor. Na margem direita está escrito: Márcio Rocha (artista). Outro dois códigos textuais formam a imagem, no entanto estão localizados dentro da moldura, ambos em negrito: Brasil 85 e $\mathrm{Cr} \$ 200$.

Como códigos imagéticos que formam, por dentro da moldura, a temática da emissão podem ser destacados: em segundo plano, e ao centro, a planta de uma estação de metrô de superfície; na margem inferior direita, um trem sobre trilhos com uma marca na lateral esquerda do primeiro vagão; acima da imagem desse trem, ampliada e destacada, percebe-se a mesma marca; na margem superior esquerda, outro trem sobre trilhos diferentes, com outra marca na lateral direita do primeiro vagão; abaixo da imagem desse trem, ampliada e destacada, percebese a mesma marca. Destaque para o fato que a maioria dos símbolos está localizada abaixo da divisão que corta a imagem na horizontal. 
A correlação dos códigos icônicos sugere a classificação deste selo como IT. Apesar de o símbolo (planta da estação) poder ser classificado como área científica (ex.: arquitetura/urbanismo), não é o foco dessa imagem. A emissão trata o metrô de superfície, no Brasil, como uma tecnologia de transporte diretamente relacionada à economia, ao transporte público urbano e às políticas públicas. Portanto, o selo tem por motivo de emissão as tecnologias e não as ciências. Essa característica específica atesta o fato da classificação dessa imagem como, apenas, tecnológica.

\section{Exemplo de Imagem Tecnocientífica (ITC):}

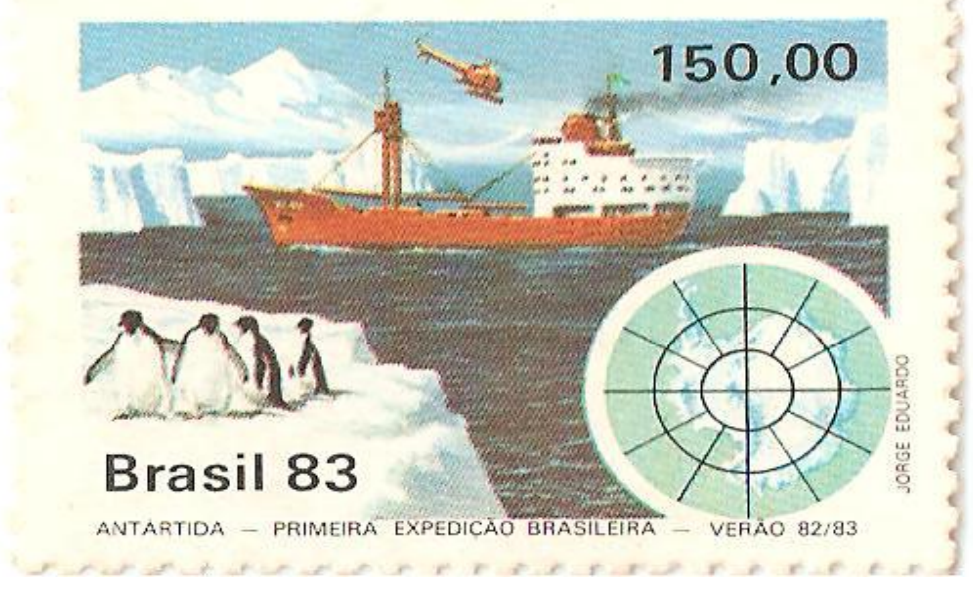

Figura 3: Imagem Tecnocientífica (ITC) - Coleção do autor

Na margem inferior, entre a moldura e a dentição, há o seguinte código textual: Antártida - Primeira Expedição Brasileira - Verão 82/83 (Salcedo, 2008, p. 6). Na margem direita está escrito: Jorge Eduardo (artista). Outros dois códigos textuais formam a imagem, no entanto estão localizados dentro da moldura, ambos em negrito: 150,00 e Brasil 83.

O que neste selo postal pode ser descrito? Seguindo o enfoque sugerido por Barthes (1990), existem três tipos de mensagem neste selo postal. A linguística (verbal), a denotada (icônica ou visual) e a conotada (simbólica ou socialmente construída).

No caso deste selo existem duas mensagens linguísticas na margem: a frase-motivo, propriamente dita: "Antártida - Primeira Expedição Brasileira - Verão 82/83" e o nome do autor do desenho: "Jorge Eduardo". Dentro do quadro estão no canto superior direito, o valor facial (cifra) "150,00", e no canto inferior esquerdo o nome do país emissor "Brasil", ao lado do ano de emissão "83". Esse é, por definição, um modelo padrão de emissão de selo postal comemorativo. A inscrição desses elementos é obrigatória para todos os selos comemorativos, conforme normas internacionais estabelecidas nas sessões da UPU. 
Para além dos padrões internacionais e, diferentemente do que ocorre com outras tipologias filatélicas, pode ser observado que os elementos verbais "Brasil" e "83" estão destacados em negrito, sobre o fundo branco de gelo. O "Brasil" confirma a presença do enunciador (Estado brasileiro) e especifica uma atividade realizada, na Antártida, por brasileiros ou pelo Brasil. A impressão do nome do país emissor, em destaque, é uma forma de o sujeito da enunciação estar presente, mas, também, porque o selo postal comemorativo circula o mundo, de projetar seu discurso nacionalista aos outros países.

Todavia, o artista que elaborou a ilustração também consta na peça. Com o detalhe que ele fica com o nome bastante reduzido e fora da ilustração, num contraste direto com "Brasil". Existem, então, um sujeito enunciador e um narrador assumido (o artista que cria os elementos verbovisuais é, em si, um enunciador projetado), com o enunciador "Estado" sobrepondo sua voz ao enunciador projetado (artista) por meio de destaques gráficos e expressivos (cor, tamanho de fonte e localização geográfica na ilustração). A abreviação do ano de emissão "83" (em vez de 1983) é uma convenção e tem relação direta com o espaço destinado à ilustração do selo.

No plano denotativo, a cifra "150,00" e "Brasil 83" são elementos referenciais de valor, espaço e tempo, respectivamente. Com relação à cifra, algumas considerações são possíveis: a falta do símbolo da moeda corrente ao lado da cifra (Cruzeiro $=\mathrm{Cr} \$$ ) pode ter relação com a questão do espaço, mas, também, com uma decisão político-econômica interna da Casa da Moeda ou, ainda, em alguma especificação no Ato Normativo. De fato, podemos dizer que a invisibilidade do signo "cifrão" é compensada pela semelhança gráfica - negrito - dado ao valor facial e ao nome Brasil. Por estarem, ambos, em negrito, sugere uma relação do país com sua moeda corrente.

Ainda sobre a cifra "150,00" é um altíssimo valor se comparado aos outros selos emitidos no mesmo ano, em que a média do valor facial ficou entre 30,00 e 45,00 cruzeiros. Logo, que tipo de missiva postal custaria 150,00 cruzeiros em 1983? Quem teria condições de pagar esse porte postal? Decerto os colecionadores e comerciantes filatélicos, como sugerem Almeida e Vasquez (2003, p. 139): "Comerciantes filatélicos aguardavam nos guichês das agências especializadas dos Correios à abertura dos trabalhos no dia do lançamento de novas emissões, adquirindo folhas inteiras, que seriam depois desmembradas para venda dos selos isoladamente".

Todavia, um outro aspecto surge do campo do não-visível e do simbólico. Por se tratar da comemoração sobre a participação brasileira na ocupação de terras polares, o valor é alto, pois estimula a internacionalização da mensagem do governo brasileiro. Apenas pessoas com poder aquisitivo alto e com relações internacionais usariam esse selo nas suas correspondências. A circulação dessa peça é voltada para um público internacional mais do que nacional. A hegemonia nacional, o discurso político-econômico e o discurso simbólico tecnocientífico são o punctum desse artefato. 
Decerto, todos os elementos linguísticos (verbais) que foram explicados têm uma função de auxiliar na compreensão dos outros elementos, sejam eles denotativos ou conotativos. Assim, pensamos que é possível dizer que o conjunto de elementos icônicos (visuais) que constituem a imagem indica que esse selo postal está, em certa medida, informando e documentando traços de cientificidade ou de uma cultura científica nacional.

Descrever apenas a parte verbal ou apenas a parte icônica acarretaria uma análise pobre, em que não se chegaria ao signo pleno. Mas, ao considerar a relação entre todos os elementos (figuras) é possível sugerir que se trata de uma tematização de cunho científico. Neste selo postal existe um discurso voltado para o científico, mas não exclusivamente.

As expressões "primeira" e "82/83" estão isoladas com relação a uma possível tematização. Não há figuras que dêem suporte icônico a esses termos. Ainda assim, analisadas isoladamente, elas constituem parte de uma oração e não de um enunciado. Apenas passam a ser consideradas constituintes de um enunciado quando analisadas no contexto da leitura completa dos elementos verbovisuais, ou como sugere Bakhtin (2003, p. 277): "essa oração assume novas qualidades e é percebida de modo inteiramente diverso de como é percebida a oração emoldurada por outras orações no contexto de um enunciado". Neste caso, não há outras orações, mas existe a linguagem icônica (denotativa) que funciona como um objeto que se relaciona com a oração, acarretando a possibilidade de enunciação.

A maneira como a tematização científica é ilustrada instiga e manifesta não apenas o imaginário sobre um lugar-espaço geográfico (Antártida, Pólo Sul, lugar frio e inóspito), ou sobre a presença da nação brasileira nesse lugar (afirmação internacional da soberania brasileira), mas, também, os investimentos do Estado em tecnologia para conseguir essa soberania e por meio da ação.

Tal ação é manifestada por três figuras: os pinguins (tem-se, em primeiro plano no canto inferior esquerdo, um grupo de quatro pinguins. Um deles, o da esquerda e mais à frente, sugere estar em movimento, pois está com as asas afastadas do corpo além de ter umas das patas erguidas). Buscam o afastamento de algo que os incomoda ou amedronta.

Outra figura é o navio em movimento ao considerar tanto as ondas na parte dianteira (proa) do casco, quanto a fumaça que sai da chaminé no sentido da sua popa. A última figura é o helicóptero, que sobrevoa o local fazendo, geralmente, reconhecimento da área. Também é utilizado como transporte de pessoas e suprimentos, entre o navio e as bases terrestres.

Esses são dois tipos de transportes utilizados pela expedição brasileira nas 'Operações Antárticas'. O navio de apoio oceanográfico Barão de Teffé (hoje inutilizado) e um helicóptero do tipo "Esquilo", bi-turbinado, ambos adquiridos pela Marinha brasileira. O navio tinha capacidade para transportar dois helicópteros. A imagem só mostra um deles em ação. As cores fortes, com 
tonalidades de vermelho ou laranja, são características desse tipo de transporte em terras geladas, por motivos de identificação e segurança.

"Com o objetivo de dar início aos trabalhos de instalação da Estação Antártica Comandante Ferraz (EACF) e de possibilitar a admissão do Brasil ao Conselho Consultivo do Tratado da Antártica, o Brasil adquiriu o Navio de Apoio Oceanográfico (NApOc) Barão de Teffé, $\mathrm{H}-42$, navio polar, com antigo nome de "Thala Dan". O navio participou de doze Operações Antárticas e serviu para fornecer apoio logístico e transporte de pessoal à EACF (EXPLORANDO..., informação eletrônica, 2009).”

Uma quarta figura enfatiza a questão da Antártida. No plano inferior direito há uma projeção cartográfica azimutal caracterizada pela projeção central dos meridianos à imagem central do mapa. Esse tipo de representação corresponde à área científica denominada Cartografia. Observa-se ainda, uma pequena inadequação na representação, pois os meridianos deveriam confluir até o ponto central, o que não ocorre nessa imagem.

A Antártida, por ser um local distante, desconhecido, inóspito e praticamente inatingível para a grande maioria das pessoas, exerce um fascínio sobre elas. Talvez, por isso, essa imagem retrate um momento de céu claro e mar calmo, sugerindo uma expedição sem infortúnios, o que é uma exceção, além de mostrar um pouco da fauna local. A claridade e a paz nessa imagem escondem o não-dito: território desconhecido, perigoso, com ambiente climático desfavorável à vida urbana etc.

A composição e harmonia entre os diversos símbolos impressos nesse selo postal comemorativo e seguindo os critérios estabelecidos neste trabalho, nos possibilita afirmar que este selo difunde elementos que caracterizam um domínio discursivo científico ou uma cientificidade. É por meio desse tipo de selos postais que os educadores das disciplinas científicas podem instigar, de forma divertida e lúdica, o olhar ainda em formação dos estudantes.

\section{Considerações Finais}

Normalmente não damos o devido valor a um selo postal. Simplesmente, no nosso corrido e ocupadíssimo cotidiano, aceitamos esse artefato como um pequeno e insignificante fragmento de papel descartável que indica a taxa a ser cobrada ao remetente de uma correspondência. Esse pequeno pedaço de papel, por vezes, nem chega a ser percebido como um documento, propriamente dito. Ele é.

O seu processo de construção tem um início, meio e fim. Além de um valor ou função social atribuído pelo Estado, é ele quem indica a tarifa corrente às comunicações postais. Mas não apenas isso. É um artefato documental que percorre o mesmo sistema de produção capitalista 
como qualquer outro objeto tecnológico, provenientes dos regimes sócio-político-econômicos trazidos à tona no pretérito europeu.

O Estado, ao produzir selos postais comemorativos, contribui para a possibilidade de que ocorra um processo de assujeitamento. Os sujeitos que constituem o tecido social, particularmente aquele de interação com o regime de informação do selo postal, assumem os discursos institucionais possíveis conforme o seu trânsito. Mas, percebemos esses sujeitos como elementos participativos e atuantes do processo comunicativo. Agentes partícipes do processo discursivo.

Sugerimos que, em certa medida, existe uma sustentação das relações sociais a partir desses códigos, divulgados e traduzidos por componentes de uma operacionalização imposta por um sistema capitalista, uma vez que gera o simulacro do desejo do consumo da 'verdade' científica. O real ou a 'verdade' científica' também é produzida com a contribuição dos selos postais comemorativos, sejam eles constituintes de acervos individuais ou coletivos, privados ou públicos.

Os selos postais detêm na sua minúscula textualidade uma incontável variedade de signos, que deixaram de ser apenas signos e são transformados em veículos de transmissão de verdades estabelecidas, de significações de mundo e de sentidos socialmente construídos. Isso implica dizer que os signos são mutáveis na ação social.

Vemos o selo postal como uma manifestação material humana. Não nos interessa olhar para esse artefato no sentido de condenar ou absolver os seus atributos discursivos, mas de enaltecer os lugares possíveis de expressão subjetiva, das transmutações históricas, figuras do pensar e sentir humanos. Não vemos nesses media apenas uma imagem ou uma frase, mas distintas qualidades verbovisuais que, entrelaçadas num processo discursivo, garantem a circulação de significantes.

O regime de informação do qual participa o selo postal implica produção, circulação e consumo do mesmo. Para cada selo emitido, novas condições de discursividade são oferecidas. Ou seja, apesar de difundir informações científicas, o selo postal apenas pode elaborar um discurso científico baseado ou determinado pelas condições próprias do regime ao qual está inserido. Além disso, pode ser oportuno ampliar essa visão e estudar, também, as possíveis representações e usos sociais do selo postal, por meio da apropriação de novos discursos ou reformulações dos mesmos, para verificar, de fato, como o selo postal difunde ciência.

Um resultado satisfatório, deste estudo, tem relação com o fato de que desenvolvemos as condições necessárias para que tanto os pesquisadores quanto o público não-pesquisador tenham a possibilidade de olhar atentamente ao selo postal como um artefato que difunde ciência e que, como afirma Gomes (2007, p. 165), "a partir de estratégias discursivo-textuais" específicas, pode ser considerado integrante do gênero divulgação científica. Mas, também 
podemos olhar esse artefato como memória sócio-científica, objeto que registra o fato, a memória, impedindo o acontecimento do esquecimento.

Talvez, depois dos caminhos que foram, até agora, percorridos, seja viável sugerir que o selo postal seja incluído, com mais afinco, nas análises dos estudos em Comunicação, História, Sociologia e Antropologia, dentre outras, posto que entendemos esse artefato em três dimensões que contribuem à construção real da sociedade: enquanto uma evidência de construção discursiva (selo postal em si), um processo de construção (Regime de Informação do selo postal) e uma construção de evidência discursiva (elementos verbovisuais).

Defendemos a utilização do selo postal também como instrumento pedagógico, como uma ferramenta de fácil manuseio, custo baixo, que provoca o processo criativo e auxilia na leitura das realidades possíveis. Os selos postais permitem mediar essas realidades, assim como fazem outros media (fotografia, cinema, novela, romances etc). A pesquisa da qual resultou este artigo nos permitiu descobrir nuances a respeito do discurso científico e algumas relações subjacentes ao seu regime de informação. Mudou a nossa forma de olhar. 


\section{LÂMINA 1 - CATEGORIA CIENTISTAS}
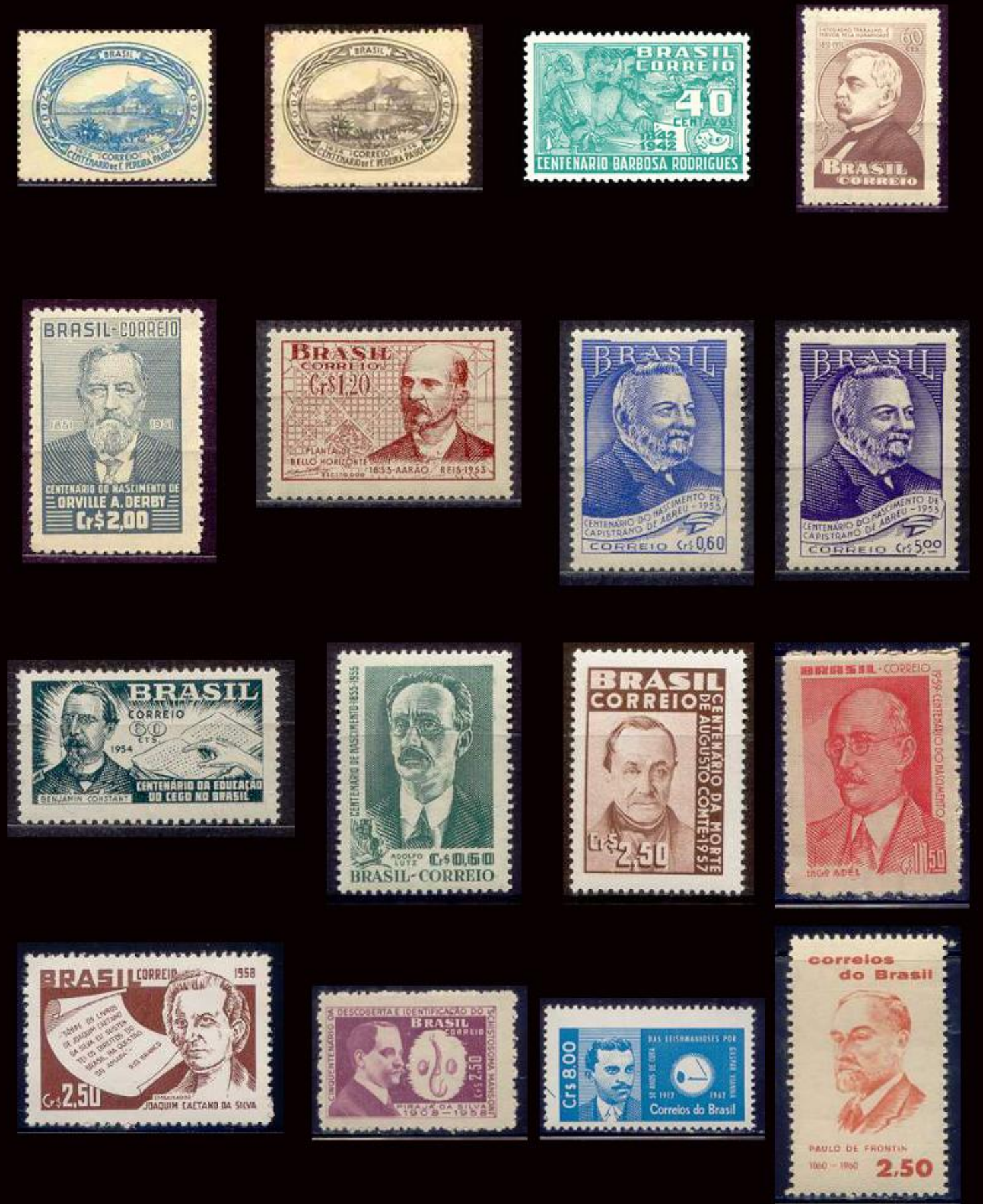


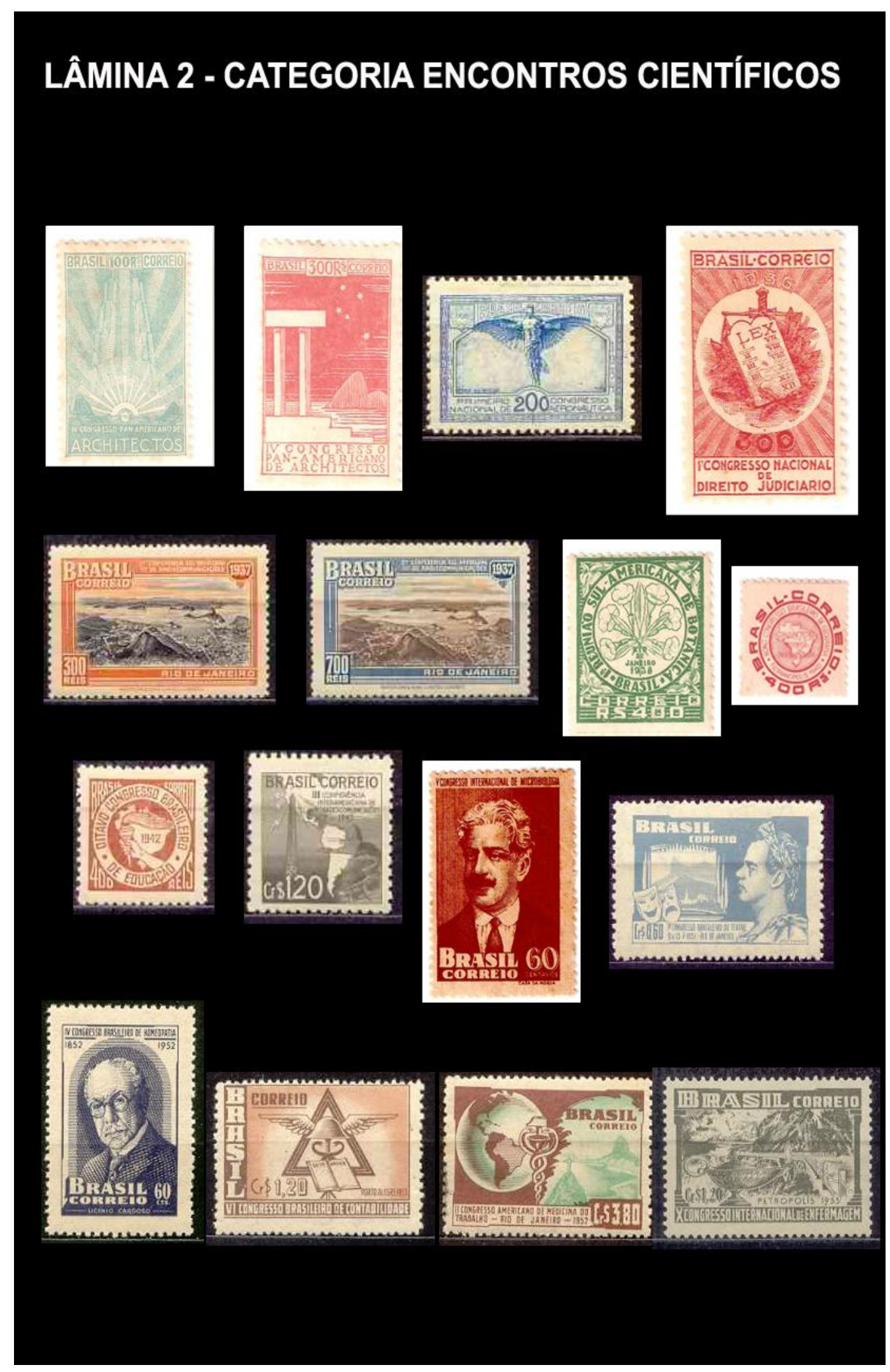

R. B. E. C. T., vol 7, núm. 2, mai-ago.2014 ISSN - 1982-873X 


\section{LÂMINA 3 - CATEGORIA INSTITUIÇÕES CIENTÍFICAS}
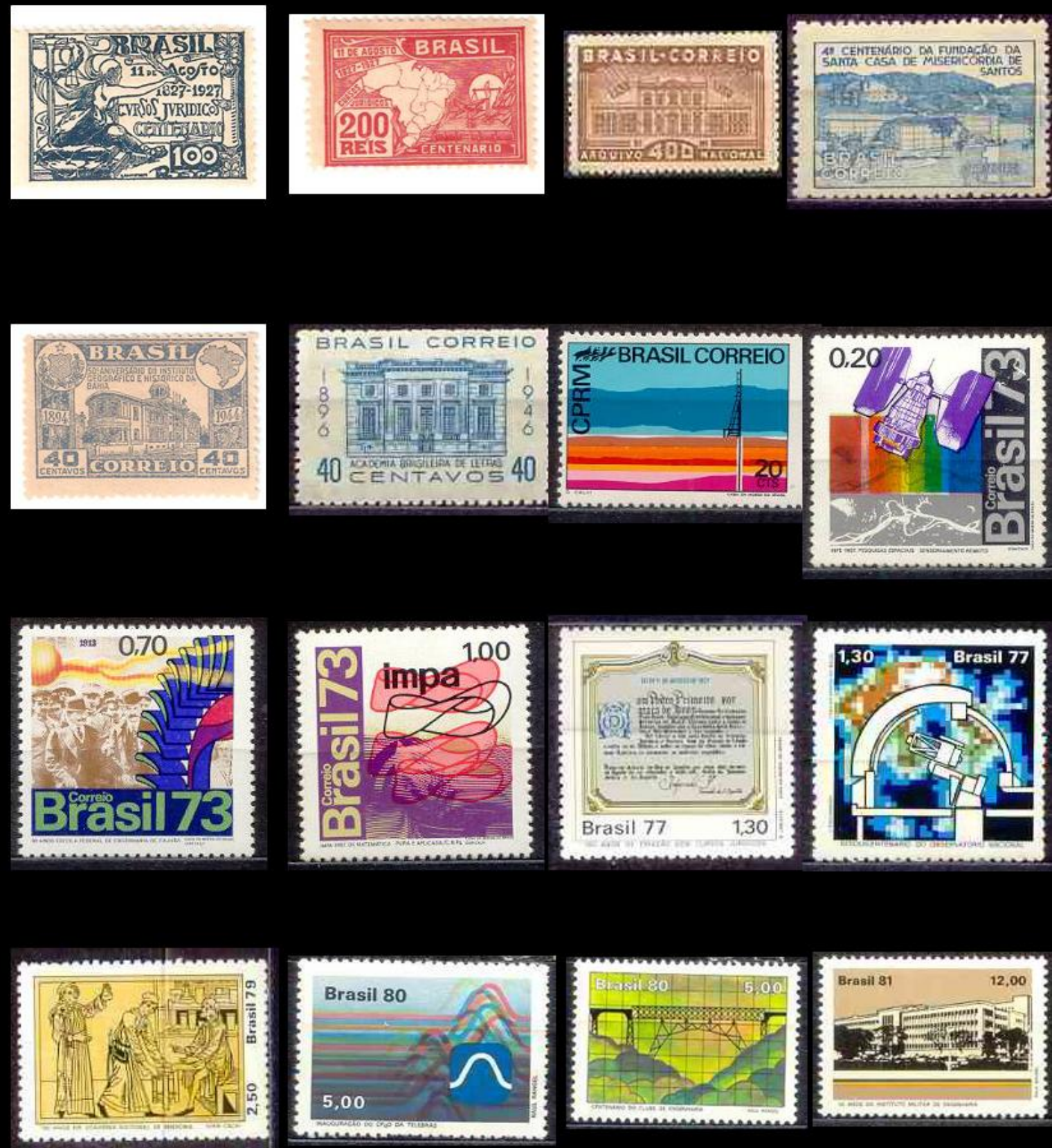


\section{LÂMINA 4 - CATEGORIA SÍMBOLOS CIENTÍFICOS}
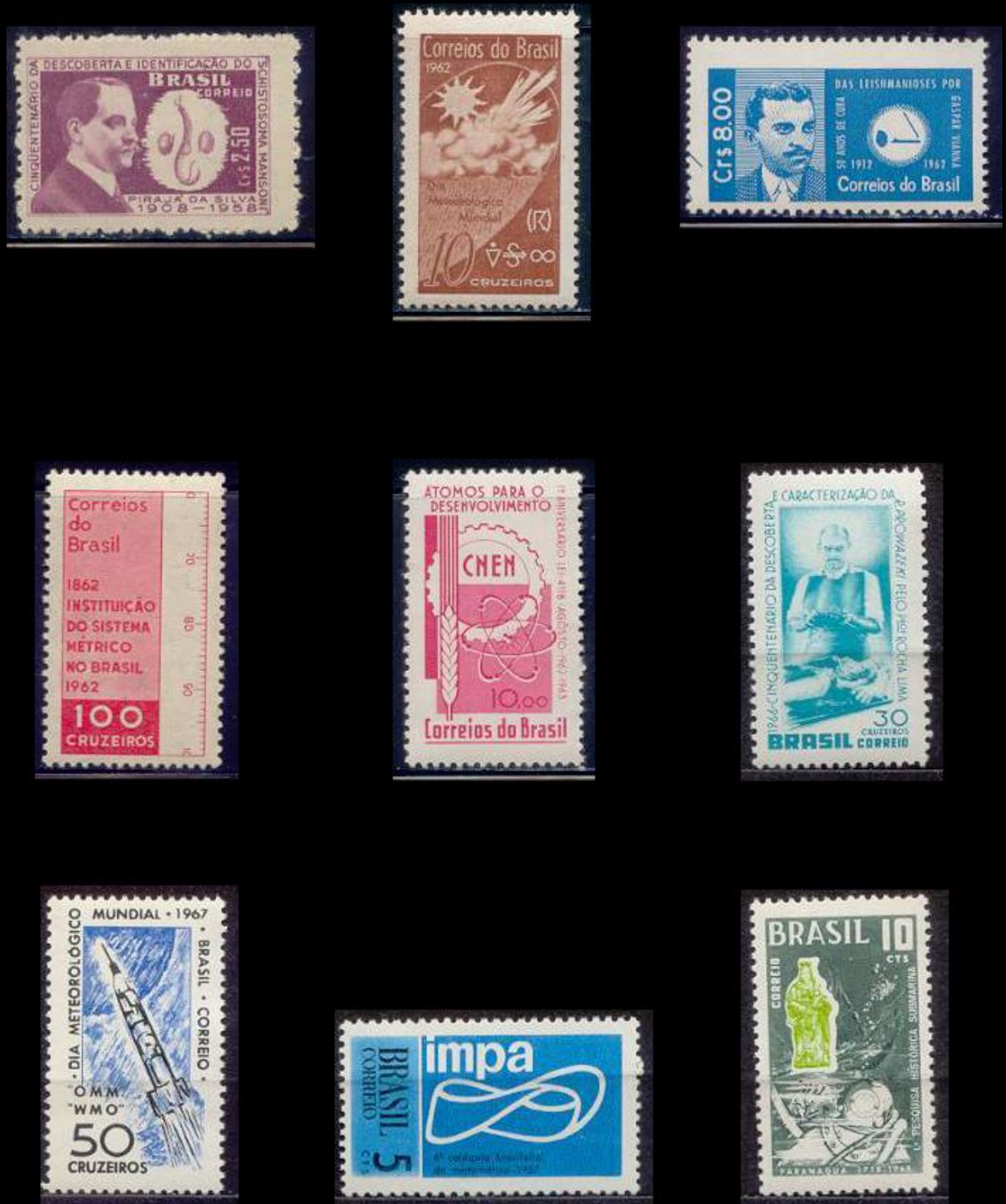


\section{Referências}

Altman, D. Paper ambassadors: the politics of stamps. North Ryde: NSW, 1991.

Almeida, Cícero Antônio de; Vasquez, Pedro Karp. Selos postais do Brasil. São Paulo: Metalivros, 2003.

Agustín Lacruz, Maria del Carmen. Análisis documental de contenido del retrato pictórico: ropuesta epistemológica e metodológica aplicada a la obra de Francisco de Goya. Cartagena: 3000 Informática, 2006.

Bachelard, G. A formação do espírito científico. 2. ed. Rio de Janeiro: Contraponto, 1996.Barthes, Barthes, Roland. 0 império dos signos. São Paulo: Martins Fontes, 2007.

O óbvio e o obtuso: ensaios críticos III. Rio de Janeiro: Nova Fronteira, 1990.

Bessis, H. A imagem da Ciência na pintura. In: VIERNE, S. A Ciência e o Imaginário. Brasília: UNB, 1994. p. 159 - 190.

Brait, Beth. (Orga.). Bakhtin: conceitos-chave. São Paulo: Contexto, 2005.

Burke, P. Testemunha ocular: História e Imagem. SP: EDUSC, 2004.

Catálogo de Selos do Brasil: completo de 1648 a 2012. 58. ed. São Paulo: RHM, 2013.

Contrera, M. S.; Baitello Jr., N. Na selva das imagens: algumas contribuições para uma teoria da imagem na esfera das ciências da comunicação. Significação. São Paulo, n. 25, jun. 2006, p. 113 126.

Cunha Filho, Paulo C. A representação visual da memória: imagens e melancolia na cidade periférica. In: Prysthon, Ângela. (Orga.). Imagens da cidade. Porto Alegre: Sulinas, 2006. p. 219234.

Damásio, A. O mistério da consciência. SP: Cia. das Letras, 2000.

Dubois, Philippe. El acto fotográfico. Barcelona: Paidós. 1986.

Eduardo, J. Antártida: primeira expedição brasileira - verão 82/83. 1983. Selo postal., Color., $21 \mathrm{~mm} \times 39 \mathrm{~mm}$. Coleção particular.

Ellul, J. A técnica e o desafio do século. SP: Paz e Terra, 1968.

Erbolato, M. L. Comunicação postal: propaganda, cultura e informação. Comunicarte, Campinas, v.1, n. 2, p. 111-123, 1983.

Goldberg, Vicki. The power of photography. New York: Abbville, 1991.

Gomes, Isaltina M. A. M; Salcedo, Diego A. A divulgação da informação científica no Jornal do Commercio. Ícone, Recife, v. 1, n. 8, p. 80-88, 2005. 
. O texto e o discurso na revista Ciência Hoje. In: Gomes, Maria Carmem Aires; Melo, Mônica Santos de Souza; Cacatldi, Cristiane. (Eds.). Gênero discursivo, mídia e identidade. Viçosa [MG]: UFV, 2007. p. 165-191.

Granger, Gilles-Gaston. A Ciência e as Ciências. SP: UNESP, 1994.

Hall, A. R.; Hall, M. B. A brief history of science. NY: American Library, 1964.

Hernández, Fernando. Catadores da cultua visual: transformando fragmentos em narrativa educacional. Porto Alegre: Mediação, 2007.

Izquierdo, I. Aumentando o conhecimento popular sobre a ciência. In: CONFERÊNCIA NACIONAL DE CIÊNCIA, TECNOLOGIA E INOVAÇÃO: desenvolvendo idéias para desenvolver o Brasil, 3, Brasília. Anais. Parcerias Estratégicas, Brasília, n. 20, parte 1, p. 113-118, jun. 2005.

Katz, C. o enfoque marxista da mudança tecnológica. In: KATZ, C.; COGGIOLA, O. Neoliberalismo ou crise do capital? SP: Xamã, 1996, p. 9 - 17.

Kneller, G. F. A ciência como atividade humana. RJ/SP: Nova Fronteira/EDUSP, 1980.

Kossoy, Boris. Fotografia e Historia. 2. ed. rev. São Paulo: Ateliê, 2003.

Meadows, A. J. A Comunicação científica. Brasília: Briquet de Lemos, 1999.

Meneses, U. T. B. de. Fontes visuais, cultura visual, história visual: balanço provisório, propostas cautelares. Revista Brasileira de História. São Paulo, v. 23, n. 45, p. 11-36, jul. 2003.

Morais, R. de. Evoluções e Revoluções da Ciência atual. SP: Alínea, 2007.

Oliveira, F. de. Jornalismo científico. 2. ed. São Paulo: Contexto, 2005.

Pinheiro, H. D.; Pinheiro, D. R. de C. Tecnologia e inovação nas sociedades capitalistas. Humanidades. Fortaleza, v. 17, n. 2, p. 157-160, ago. - dez. 2002.

Pirró e Longo, W. Ciência e a Expressão Militar do Poder Nacional: histórico de interação. A Defesa Nacional. n. 732, 1987.

Ciência e Tecnologia: evolução, inter-relação e perspectivas. In: ENCONTRO NACIONALDE ENGENHARIA DE PRODUÇÃO. 1989. Anais... v. 1, 42, 1989. 13 p.

Raento, Pauliina; Brunn, Stanley. Visualizing Finland: potage stamps as political messengers. Geografiska Annaler, n. 87, p. 145-164, 2005.

Rocha, M. Metrô de superfície no Brasil: custo menor, transporte melhor. 1985. Selo postal, Color., $21 \mathrm{~mm}$ x 39mm. Coleção particular.

Centenário do nascimento de Gilberto Freyre. 2000. Selo postal, Color., 59mm x 25mm (vertical). Coleção particular. 
Rosa, L. P. Tecnociências e humanidades: novos paradigmas, velhas questões. SP: Paz e Terra, 2005.

Salcedo, Diego A. Lacunas na Arquivologia contemporânea: uma perspectiva da Filatelia. Arquivstica.net, Rio de Janeiro, v. 2, n. 1, 2006. Disponível em: <http://www.arquivistica.net>. A visibilidade da Ciência nos selos postais comemorativos. In: SEMINÁRIO NACIONAL DE PESQUISA EM CULTURA VISUAL. 1, 2008, Goiânia. Anais... Goiânia, UFG, 2008, 10 p.

A ciência nos selos postais comemorativos brasileiros: 1900-2000. Recife: EDUFPE, 2010.

Originalmente apresentada como Dissertação de Mestrado em Comunicação, Universidade Federal de Pernambuco, 2010.

Espelhos de papel: pelo estatuto do selo postal. Recife: EDUFPE: 2013. (prelo) Originalmente apresentada como Tese de Doutorado em Comunicação, Universidade Federal de Pernambuco, 2013.

Santaella, Lúcia; Noth, Winfried. Imagem: cognição, semiótica, mídia. 4. ed. São Paulo: Iluminuras, 2005.

Schumpeter, J. A teoria do desenvolvimento econômico. 3. ed. SP: Nova Cultura, 1988.

Tacca, Fernando de. Fotografia e olhar totalitário: uma análise da imagem nazista. Imagens. Campinas, n. 5, p. 99-105, 1995.

. A imagética da Comissão Rondon. Campinas: Papirus, 2001. Imagem fotográfica: aparelho, representação e significação. Psicologia e Sociedade. Santa Catarina, v. 13, n. 3, p. 9-17, set. - dez., 2005.

Diego Andres Salcedo - Doutor em Comunicação. Professor no Dep. de Ciência da Informação da UFPE. Email: salcedo.da@gmail.com 